\title{
The role of gold nanoparticles on taxol-induced renal cortex damage in adult male albino rats
}

\author{
Original \\ Article \\ Samah M. Ahmed, Maha Z. Mohammed and Abeer A. Mahmoud \\ Department of Histology and Cell Biology, Faculty of Medicine, Zagazig University, Zagazig, \\ Egypt
}

\begin{abstract}
Introduction: Taxol is a chemotherapeutic drug widely used in the treatment of various types of cancer. Nephrotoxicity is the most hazardous effect complicating chemotherapy.

Aim of the work: This research aimed to evaluate the effect of gold nanoparticles on taxol induced nephrotoxicity.

Materials and Methods: Thirty adult Wistar male albino rats were divided into three equal groups: the control group (group I) this group was equally subdivided into two subgroups. Taxol-treated group (group II) and gold nanoparticles (GNP)treated group (group III). Rats in group II received $0.6 \mathrm{mg} / \mathrm{kg}$ body weight Taxol intraperitoneally as a single dose. Animals of group III received Taxol as Group II and after 48 hours, GNPs ( $400 \mu \mathrm{g} / \mathrm{kg}$ body weight) was administered intravenously via the tail vein daily for 14 days. Kidney function tests were studied. kidney sections were stained with Hematoxylin and Eosin (H\&E), Mallory trichrome stain, periodic acid schiff (PAS) reaction and immunohistochemical analysis for inducible nitric oxide synthase (iNOs).

Results: Taxol-treated group showed congested glomerular capillaries, cellular infiltration, extravasation and vacuolated tubular cells. Fibrosis in the interstitium was noticed by Mallory trichrome. PAS stained sections showed weak reaction at the brush border of tubular cells. Strong positive reaction for iNOs in the cytoplasm of tubular cells was also noticed. All these changes were improved in GNP-treated group.

Conclusion: From the present study, the gold nanoparticles application is promising in the treatment of taxol nephrotoxicity.
\end{abstract}

Received: 22 February 2018, Accepted: 15 June 2018

Key Words: Gold nanoparticles, histology, rat kidney, taxol.

Corresponding Author: Abeer A. Mahmoud, Department of Histology and Cell Biology, Faculty of Medicine, Zagazig University, Zagazig, Egypt, Tel.: 01004055839, E-mail: abeerazeem@hotmail.com.

ISSN: $1110-0559$, Vol. 41, No. 3

\section{INTRODUCTION}

Nanomedicine is rapidly progressing field, whereasnanoparticles (NPs) may have the ability to overcome certain biological and physical barriers where conventional therapies fail. Particle size is typically between $100 \mathrm{~nm}$ and $300 \mathrm{~nm}$, although many formulations and applications call for smaller sizes. They have been found to improve therapeutic efficacy and reduce treatment side effects in some cases ${ }^{[1]}$.

Besides, nanoparticles offer a great possibility for biomedical application, not only for drug delivery, but also to be used as novel diagnostic and therapeutic approaches ${ }^{[2]}$.

Nanotechnology is increasingly used in drug delivery because the unique physicochemical properties of nanoparticles (size, surface charge, hydrophilicity, and presence of targeting moieties on the particle surface) help to overcome barriers commonly limiting the efficacy of traditional small and macromolecular drugs. Nanoparticles can improve solubility, pharmacokinetics, and biodistribution of traditional pharmaceuticals ${ }^{[3]}$.

Acute kidney injury (AKI) and electrolyte disturbances are the most common forms of renal diseases that may occur in a hospitalized cancer patient. Important factors potentiating AKI in these patients are extracellular volume depletion due to vomiting, diarrhoea, urinary tract obstruction, fluid and electrolyte disturbances, exposure to contrast media, nephrotoxic antibiotics, non-steroidal antiinflammatory drugs and nephrotoxicity of some of the anticancer treatments ${ }^{[4,5]}$.

Taxol (generic name paclitaxel) is a microtubulestabilizing drug widely used for the treatment of many types of cancer. It has been recognized to induce mitotic division arrest, which leads to cell death. Paclitaxel-induced mitotic arrest occurs due to activation of the mitotic checkpoint (also known as the spindle assembly checkpoint) ${ }^{[6,7]}$.

Nephrotoxicity is the most dangerous complication of chemotherapy in general, and kidney functions must be monitored regularly during any chemotherapeutic course ${ }^{[8]}$. 
Cancer patients may develop a variety of kidney lesions that impair not only their immediate survival, but also limits the adequate treatment of the underlying malignant process $^{[9]}$.

The histological and immunohistochemical alterations in the renal tissues due to taxol have not well documented.

The present study is an attempt to demonstrate the possible histological alterations in the renal cortex following taxol administration and the potential role of gold nanoparticles.

\section{MATERIALS AND METHODS}

\section{Drugs and chemicals}

Taxol (paclitaxil) injection: 1 vial $100 \mathrm{mg}(6 \mathrm{mg} / \mathrm{ml})$ "Bristol- Myers Squibb".

Gold nanoparticles: (Product Number: 742007-57-5, $50 \mathrm{~nm}$ diameter, OD-1, Stabilized suspension in $0.1 \mathrm{mM}$ phosphate buffered saline) were purchased from SigmaAldrich (St Louis, MO, USA).

\section{Animals}

Thirty adult Wistar male albino rats (220-250) g were purchased from the Breading Animal House, Faculty of Medicine, Zagazig University, Zagazig, Egypt. They were housed under standard laboratory conditions at a temperature $\left(23 \pm 2{ }^{\circ} \mathrm{C}\right)$, humidity $(54 \pm 5 \%)$. They were maintained on standard laboratory food and water ad libitum throughout the period of the experiment. All experimental procedures were approved and carried out in accordance with the guidelines of the Institutional Animal Care and Use Committee accepted by Faculty of Medicine, Zagazig University, Zagazig, Egypt.

\section{Experimental design}

Rats were divided equally into three groups:

Group I (control group): this group was equally subdivided into two subgroups: Subgroup Ia: (negative control group), rats of this group received no treatment. Subgroup Ib: each rat received intravenous GNPs $(400 \mu \mathrm{g} /$ $\mathrm{kg}$ body weight) in the tail vein daily for 14 days $^{[10]}$.

Group II (Taxol-treated group): each rat received 0.6 $\mathrm{mg} / \mathrm{kg}$ body weight of Taxol intraperitoneally as a single dose. Rats of this group were sacrificed 48 hours following taxol intake ${ }^{[8]}$.

Group III (GNP-treated group): each rat received 0.6 $\mathrm{mg} / \mathrm{kg}$ body weight of Taxol intraperitoneally as a single dose. Rats of this group started GNPs treatment after 48 hours following taxol intake. Each rat was administered GNPs (400 $\mu \mathrm{g} / \mathrm{kg}$ body weight) intravenously via the tail vein daily for 14 days $^{[10]}$

At the end of the experiment, rats were anaesthetized with intraperitoneal injection of pentobarbitone sodium 60 $\mathrm{mg} / \mathrm{kg}$ body weight. A midline incision was done on the anterior aspect of the chest, sternocostal junctions were cut, blood samples were collected from the abdominal aorta and the serum was harvested and stored at $-20^{\circ} \mathrm{C}$ for the assessment of kidney functions. Samples from the kidneys were fixed in 10\% neutral buffered formalin and processed for preparation of paraffin sections for histological: $\mathrm{H} \& \mathrm{E}^{[11]}$ Mallory trichrome stain ${ }^{[12]}$, PAS reaction, ${ }^{[12]}$ and immunohistochemical analysis for iNOs ${ }^{[13]}$.

\section{Methods}

\section{Gold nanoparticle characterization}

To study the gold nanoparticles size and morphology, the aqueous dispersion of the nanoparticles was drop cast onto a carbon coated copper grid. The grid was air dried at room temperature ${ }^{[10]}$ and visualized using Transmission Electron Microscope (JEOL JEM -2100, Joel Ltd, Tokyo, Japan) at Electron Microscope Research Unit, Faculty of Agriculture, Mansoura University, Egypt.

\section{Biochemical study}

Four $\mathrm{ml}$ of venous blood was collected in a capillary tube by retro-orbital puncture from each rat in each group. The samples were centrifuged at 3000 round per minute to separate the serum. The samples were maintained in a freezer at $-20^{\circ} \mathrm{C}$. Blood urea and serum creatinine were measured in all rats. Measurements were estimated by the conventional colorimetric method using Quanti Chrom TM assay kits ${ }^{[14]}$.

\section{Histological study}

Paraffin sections (5 $\mu \mathrm{m}$ thick) stained with $\mathrm{H} \& \mathrm{E}$ for examination of overall morphology and Mallory trichrome stain for examination of collagen fibers and PAS reaction for demonstration of carbohydrates.

\section{Immunohistochemical study}

Immunohistochemical reaction was carried out using the avidin-biotin peroxidase complex (Dakocompany, Wiesentheid/Bavaria, Germany, Biotin Blocking System, Code X0590) method following the manufacturer's instructions. $4 \mu \mathrm{m}$ serial sections of paraffin embedded specimens were deparaffinized on positive charged slides. The sections were incubated in $0.1 \%$ hydrogen peroxide for $10 \mathrm{~min}$ to block the endogenous peroxidase activity and then incubated with the primary antibody. The primary 
antibody used for iNOs was ready-to-use rabbit polyclonal antibody (CAT-No. RB-9243-R7). The slides were incubated with the secondary anti-rabbit antibody versal kits (Zymed laboratories), diluted 1:200 for 30 minutes. Staining was completed by incubation with chromogen, called diamiobenzidine (DAB). Mayer's hematoxylin was used as a counterstain ${ }^{[13]}$.

\section{Histo-morphometric study}

The image analyser computer system Leica Qwin 500 (Leica Ltd, Cambridge, UK) in the image analysing unit of the Pathology department, Faculty of Dentistry, Cairo University, Cairo, Egypt, was used to evaluate the area percentage (area \%) of the collagen fibers in Mallory trichrome stained sections, the optical density of PAS stained sections and the optical density of immunoreaction for iNOs using the immunostained sections. It was measured using the interactive measure menu. The area percentage and standard measuring frame of a standard area equal to $118476.6 \mathrm{~mm} 2$ were chosen from the parameters measuring 10 readings from five sections from each rat of the randomly chosen five rats in each group. In each chosen field, the section of the kidney was enclosed inside the standard measuring frame; the area where collagen fibers, PAS positive reaction and brown positive immune reaction for iNOs was masked by binary colour to be measured. These measurements were obtained by total magnification $\times 400$ with the area $\%$ of collagen fibers and the optical density for both PAS reaction and the immune reaction for iNOs.

\section{Statistical analysis}

Data from all groups were expressed as the mean $\pm \mathrm{SD}(\mathrm{X} \pm \mathrm{SD})$. The data obtained from the image analyser and the biochemical data were subjected to SPSS program version 14 (Chicago, Illinois, USA). Statistical analysis using the one-way analysis of variance test was carried out. The results were considered statistically significant as $P$ value was less than 0.05 .

\section{RESULTS}

\section{Gold nanoparticle characterization}

Transmission Electron Microscopic examination of GNPs revealed that their diameter was in the range of 40-50 nm (Fig.1).

\section{Biochemical results:}

Marked affection of the renal function characterized by a significant increase in the blood urea and serum creatinine $(\mathrm{mg} / \mathrm{dl})$ levels in taxol-treated group as compared to the control levels. These data indicated that taxol impaired the kidney function. Returning of blood urea and serum creatinine levels nearly to the normal levels in GNP-treated group was also observed.

\section{Histological results}

Histological examination of the control subgroups showed similar morphological results. So, subgroup Ia was considered as the control group.

H\&E stained sections of the control renal cortex in adult male albino rats showed the renal corpuscles, proximal (PCT) and distal (DCT) convoluted tubules with minimal interstitium. Each renal corpuscle consisted of a glomerulus surrounded by parietal and visceral layers of Bowman's capsule enclosing Bowman's space (Fig. 2). Taxol-treated renal cortex showed focal areas of renal affection; Renal corpuscles containing Glomeruli with congested capillaries. Cellular infiltration and extravasation were seen between renal tubules. Some renal tubules were lined by tubular cells with detached basal lamina while others had dark apoptotic nuclei (Fig. 3). Other sections in taxol-treated group showed marked vacuolations in the cytoplasm of glomerular capillary endothelium. Parietal layer of Bowman's capsule was irregular. Tubular cells were also detected with dark stained nuclei and marked cytoplasmic vacuolations (Fig.4). In GNPtreated group marked improvement in the histological structure of renal cortical tissue, the glomerulus is surrounded by parietal and visceral layers of Bowman's capsule enclosing the Bowman's space. Proximal convoluted tubules were lined by tubular cells with vesicular nuclei. Some DCT were normal except few tubules that were lined by some tubular cells with dark stained nuclei (Fig. 5).

Mallory trichrome stained sections of the control group showed minimal collagen fibers among the glomerular capillaries and in the interstitium between renal tubules (Fig.6), that was markedly increased around blood vessels and in-between the renal tubules in taxol-treated group (Fig.7). Mallory trichrome stained sections of GNP-treated group showed few collagen fibers among the glomerular capillaries and in the interstitium between renal tubules as compared to the control group (Fig.8).

PAS stained sections of the control renal cortex revealed strong positive reaction at the basal lamina of the glomerular capillary endothelium, tubular cells and the brush border of PCT (Fig.9). Faint PAS positive reaction was detected at the basal lamina of the glomerular capillary endothelium, tubular cells and the brush border of PCT in taxol-treated group (Fig.10). PAS stained sections of GNPtreated group revealed strong positive reaction at the basal lamina of the glomerular capillary endothelium, tubular cells and the brush border of some PCT as compared to the control group (Fig.11).

\section{Immunohistochemical results}

Immunohistochemical staining for iNOs immunoreaction of the control group revealed faint positive immunoreaction in the cytoplasm of renal tubular cells. Negative immunoreaction in the cytoplasm of glomerular capillary endothelium was also observed (Fig. 12). Strong positive immunoreaction was detected in the cytoplasm 
of renal tubular cells and some capillary endothelial cells in taxol-treated group (Fig. 13). In GNP-treated group, weak positive immunoreaction in the cytoplasm of renal tubular cells was detected. Negative immunoreaction in the cytoplasm of glomerular capillary endothelium was also observed as compared to the control group (Fig. 14).

\section{Histo-morphometric and statistical results}

Highly statistically significant increase in the mean area $\%$ of collagen fibers was detected in group II as compared to the control and GNP-treated groups. No statistically significant difference between the control group and GNP-treated group (Table 1).

Statistically significant decrease in the mean optical density of PAS reaction was detected in group II as compared to the control and GNP-treated groups. No statistically significant difference between the control group and GNP-treated group (Table 2).

Statistically significant increase in the the optical density iNOs immunoreaction was detected in group II as compared to the control and GNP-treated groups. No statistically significant difference between the control group and GNP-treated group (Table 3).

Highly statistically significant increase $(P<0.001)$ of the mean values of blood urea level in taxol-treated group as compared to the control and GNP-treated groups. No statistically significant difference between the control and GNP-treated group (Table 4).

Statistically significant increase $(P<0.05)$ of the mean values of serum creatinine level in taxol-treated group as compared to the control and GNP-treated groups. No statistically significant difference between the control and GNP-treated group (Table 5).

Table 1: Area percent of collagen fibers in the different studied groups

\begin{tabular}{lccc}
\hline Group & Mean \pm SD & F & $P$-value \\
\hline Control & $0.112 \pm 0.01$ & & $<0.001^{* *}$ \\
Taxol treated & $0.786 \pm 0.02$ & 218.531 & \\
GNP treated & $0.124 \pm 0.06$ & \\
\hline
\end{tabular}

Table 2: Optical density of PAS reaction in the different studied groups

\begin{tabular}{lccc}
\hline Group & Mean $\pm \mathrm{SD}$ & $\mathrm{F}$ & $P$-value \\
\hline Control & $3.12 \pm 1.22$ & & $<<0.001^{* *}$ \\
Taxol treated & $0.82 \pm 2.41$ & 26.153 & \\
GNP treated & $2.91 \pm 1.13$ & \\
\hline
\end{tabular}

Table 3: Optical density of iNOs immunoreaction in the different studied groups

\begin{tabular}{lccc}
\hline Group & Mean \pm SD & F & $P$-value \\
\hline Control & $22.003 \pm 0.02$ & & $<0.01 *$ \\
Taxol treated & $70.005 \pm 1.14$ & 10.14 & \\
GNP treated & $25.107 \pm 0.35$ & \\
\hline
\end{tabular}


Table 4: Mean blood urea levels (mg/dl) using ANOVA test in different studied groups.

\begin{tabular}{lcc}
\hline Group & Mean \pm SD & F \\
\hline Control & $31 \pm 2$ & 17.8 \\
Taxol treated & $61 \pm 3$ & $<0.001 * *$ \\
GNP treated & $35 \pm 6$ & \\
\hline
\end{tabular}

Table 5: Mean serum creatinine ( $\mathrm{mg} / \mathrm{dl})$ levels using ANOVA test in different studied groups

\begin{tabular}{lccc}
\hline Group & Mean $\pm \mathrm{SD}$ & $\mathrm{F}$ & $P$-value \\
\hline Control & $0.8 \pm 0.53$ & & $<0.01 *$ \\
Taxol treated & $1.6 \pm 0.7$ & 3.923 & \\
GNP treated & $1 \pm 0.2$ & \\
\hline
\end{tabular}

* Significant $(P<0.05)$

$* *$ Highly Significant $(P<0.001)$

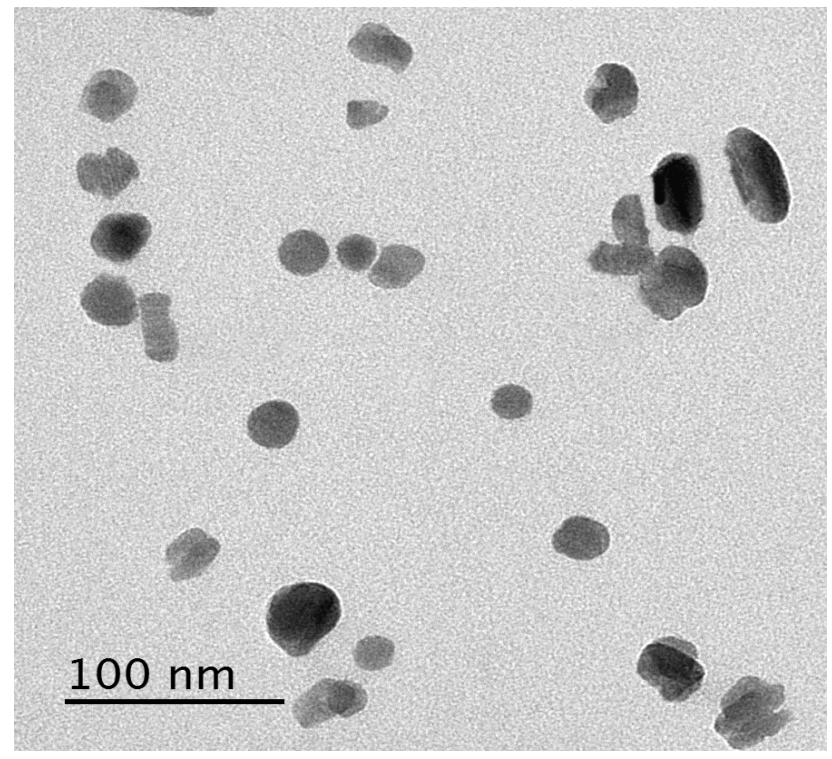

Fig. 1: An electron micrograph showing GNPs of diameter 40-50 nm.

$($ TEM $\times 50000$ Scale bar; $100 \mathrm{~nm})$

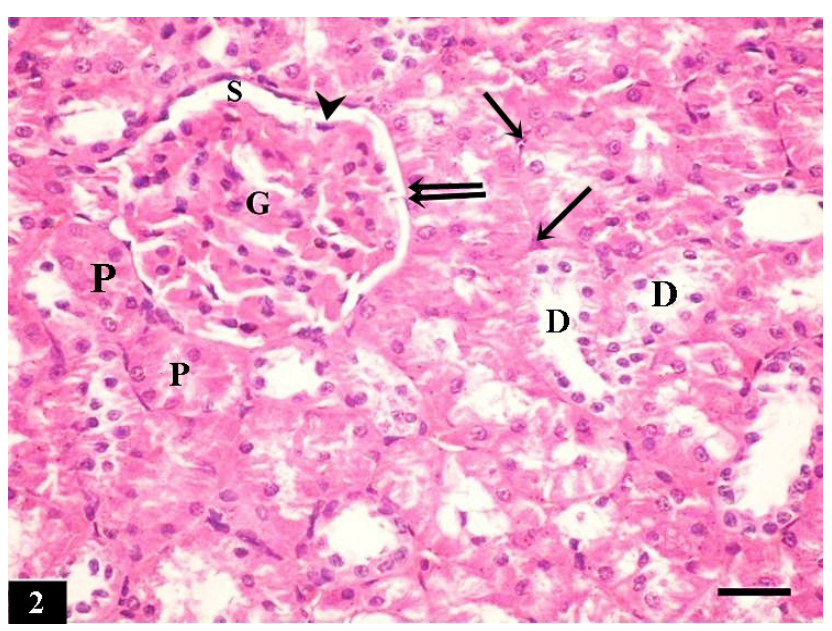

Fig. 2: A photomicrograph of $H \& E$ stained sections of the control renal cortex in adult male albino rats showing the renal corpuscle, proximal (P) and distal (D) convoluted tubules with minimal interstitium (arrow). Each renal corpuscle consists of glomerulus $(\mathrm{G})$ that is surrounded by parietal (double arrow) and visceral (arrow head) layers of Bowman's capsule enclosing the

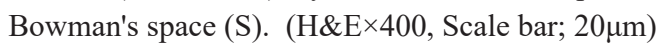




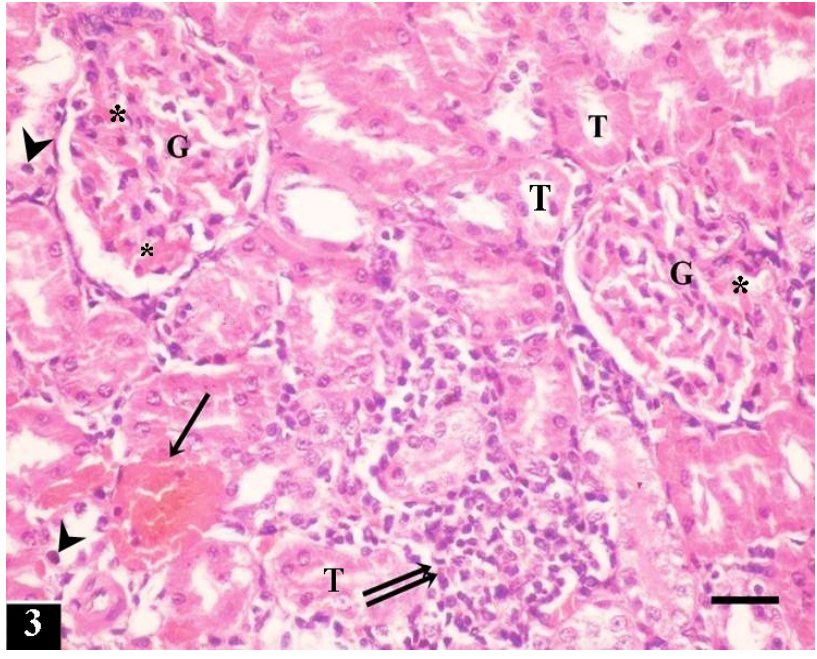

Fig. 3: A photomicrograph of H\&E stained sections of Taxoltreated renal cortex in adult male albino rats showing focal areas of renal affection; Glomeruli $(\mathrm{G})$ with congested capillaries $\left(^{*}\right)$, cellular infiltration (double arrow), extravasation (arrow). Some renal tubules $(\mathrm{T})$ are lined by tubular cells with detached basal lamina, while others have dark apoptotic nuclei (arrow head).

(H\&E $\times 400$, Scale bar; $20 \mu \mathrm{m})$

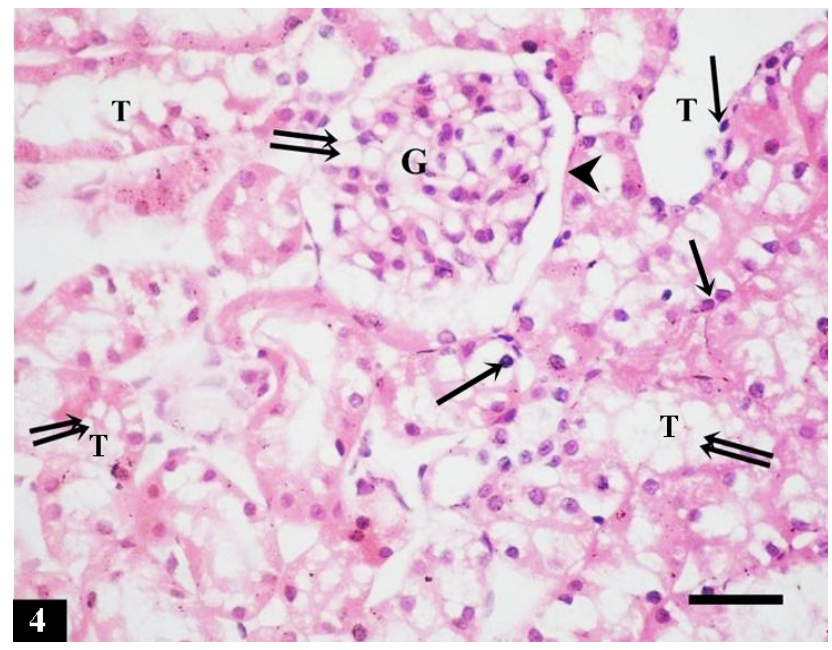

Fig. 4: A photomicrograph of H\&E stained sections of Taxoltreated renal cortex in adult male albino rats showing some sections with marked vacuolations (double arrow) in the cytoplasm of glomerular (G) capillary endothelium. Parietal layer (arrow head) of Bowman's capsule is irregular. Some renal tubules (T) are lined by cells with dark stained nuclei (arrow) and others with marked cytoplasmic vacuolations (double arrow).

$(\mathrm{H} \& \mathrm{E} \times 400$, Scale bar; $20 \mu \mathrm{m})$

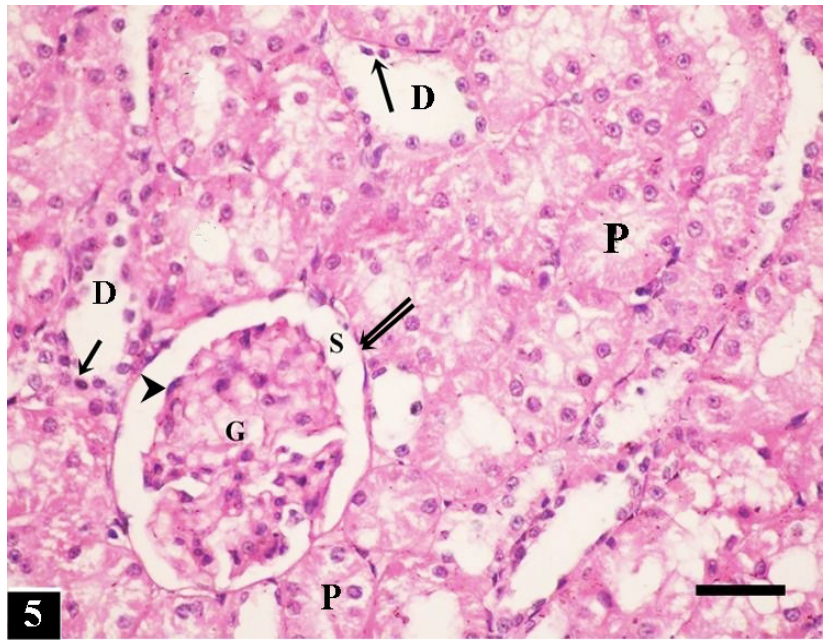

Fig. 5: A photomicrograph of H\&E stained sections of GNPtreated renal cortex in adult male albino rats showing the glomerulus $(\mathrm{G})$ is surrounded by parietal (double arrow) and visceral (arrow head) layers of Bowman's capsule enclosing the Bowman's space (S). PCT (P) are lined by tubular cells with vesicular nuclei. Some DCT (D) are normal except few tubules that are lined by some tubular cells with dark stained nuclei

(arrow). (H\&E×400, Scale bar; $20 \mu \mathrm{m})$

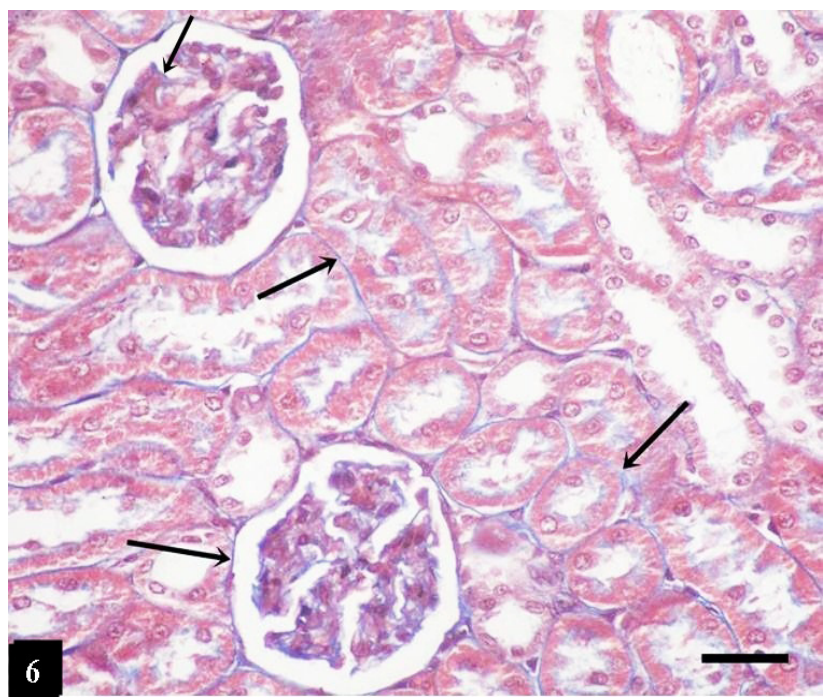

Fig. 6: A photomicrograph of Mallory trichrome stained sections of the control renal cortex showing minimal collagen fibers (arrow) among the glomerular capillaries and in the interstitium in-between the renal tubules.

(Mallory trichrome $\times 400$, Scale bar; $20 \mu \mathrm{m}$ ) 


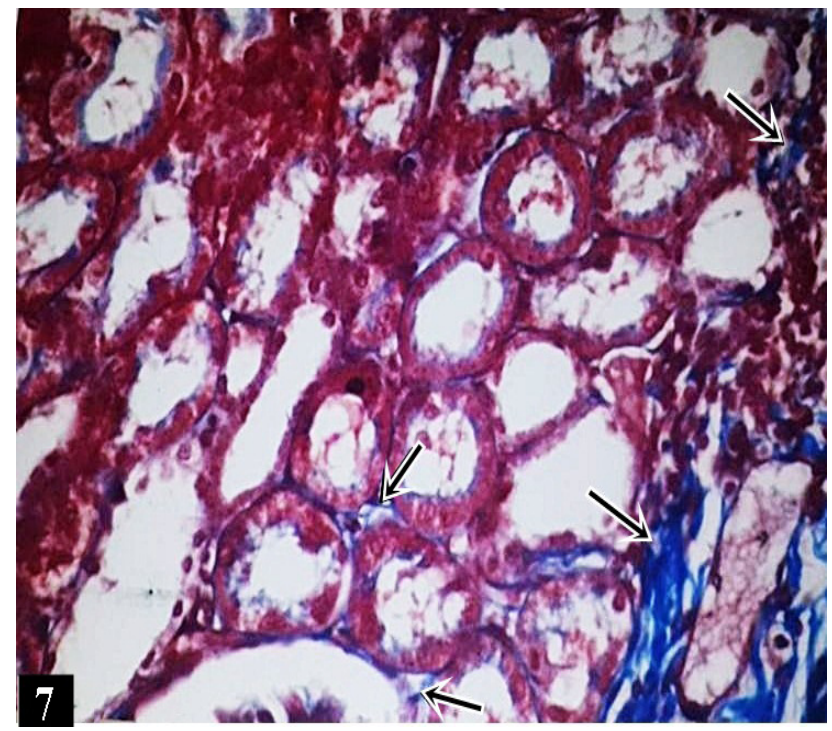

Fig. 7: A photomicrograph of Mallory trichrome stained sections of the Taxol-treated group showing many collagen fibers (arrow) around blood vessels and in the interstitium between the renal tubules.

(Mallory trichrome $\times 400$, Scale bar; $20 \mu \mathrm{m}$ )

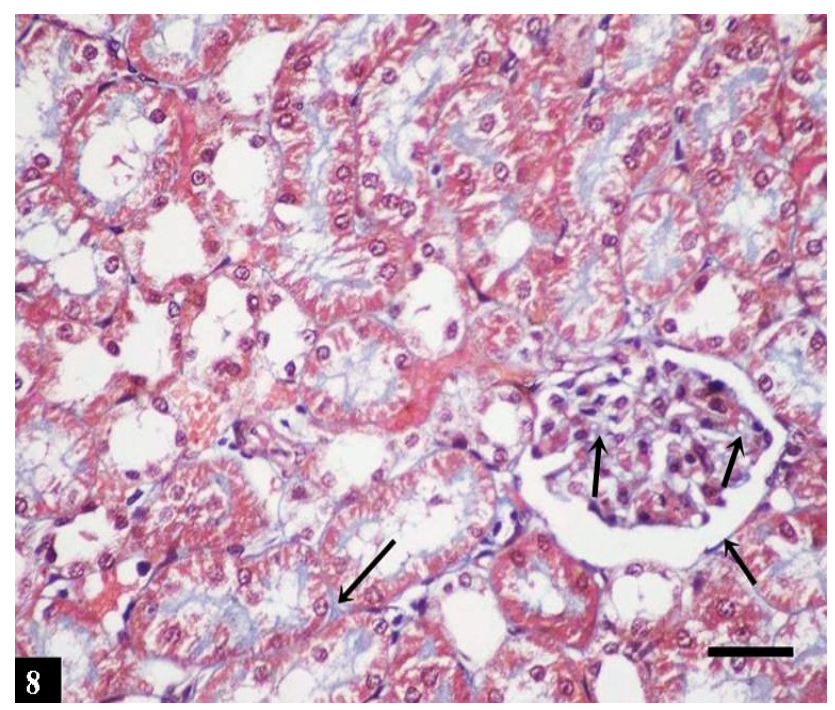

Fig. 8: A photomicrograph of Mallory trichrome stained sections of the GNP-treated group showing few collagen fibers (arrow) among the glomerular capillaries and in the interstitium between the renal tubules.

(Mallory trichrome $\times 400$, Scale bar; 20 $\mu \mathrm{m}$ )

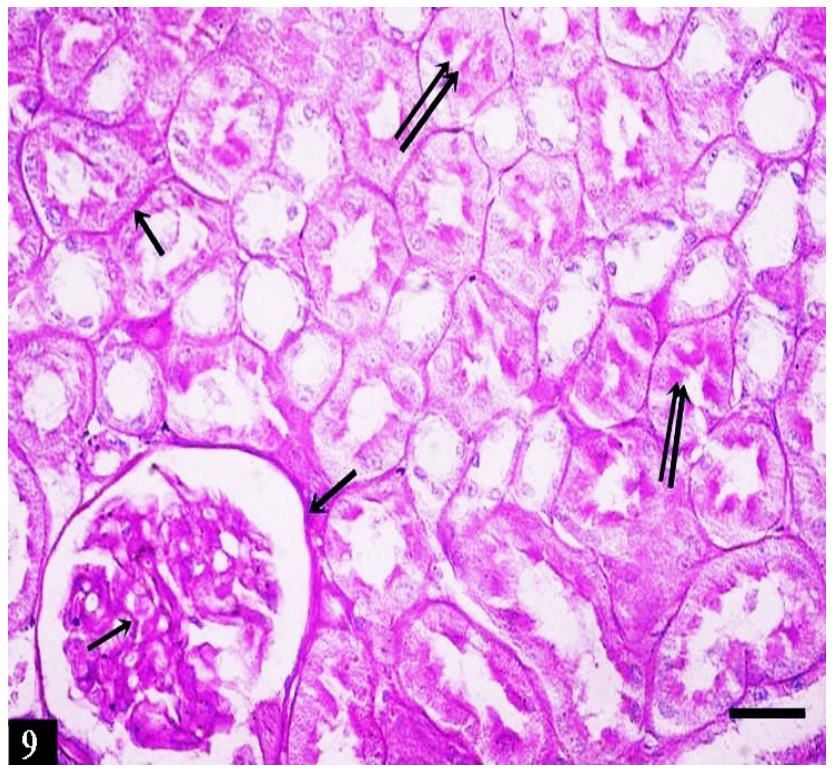

Fig. 9: A photomicrograph of PAS stained sections of the control group reveals a strong PAS positive reaction at the basal lamina (arrow) of the glomerular capillary endothelium, tubular cells and the brush border of PCT (double arrow).

(PAS $\times 400$, Scale bar; $20 \mu \mathrm{m})$

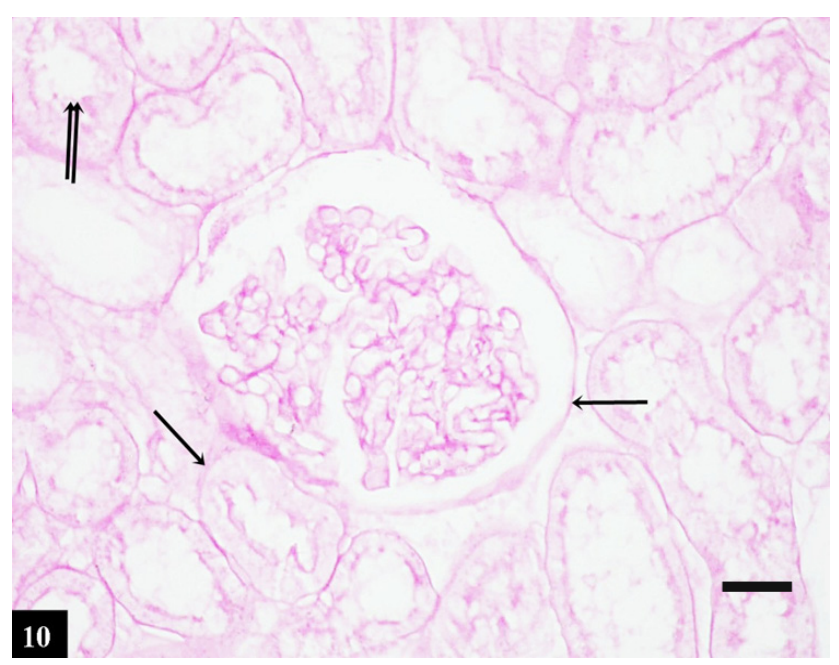

Fig. 10: A photomicrograph of PAS stained sections of taxoltreated group showing faint PAS positive reaction at the basal lamina (arrow) of the glomerular capillary endothelium, tubular cells and the brush border of PCT (double arrow).

(PAS $\times 400$, Scale bar; $20 \mu \mathrm{m})$ 


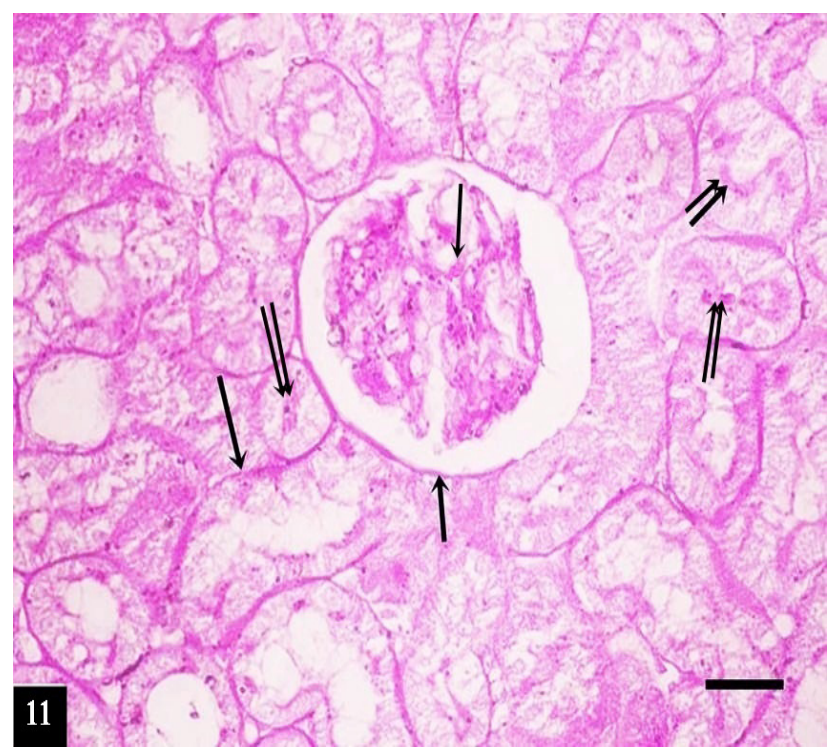

Fig. 11: A photomicrograph of PAS stained sections of GNPtreated group showing strong positive reaction at the basal lamina (arrow) of the glomerular capillary endothelium, tubular cells and the brush border of some PCT (double arrow).

$(\mathrm{PAS} \times 400$, Scale bar; $20 \mu \mathrm{m})$

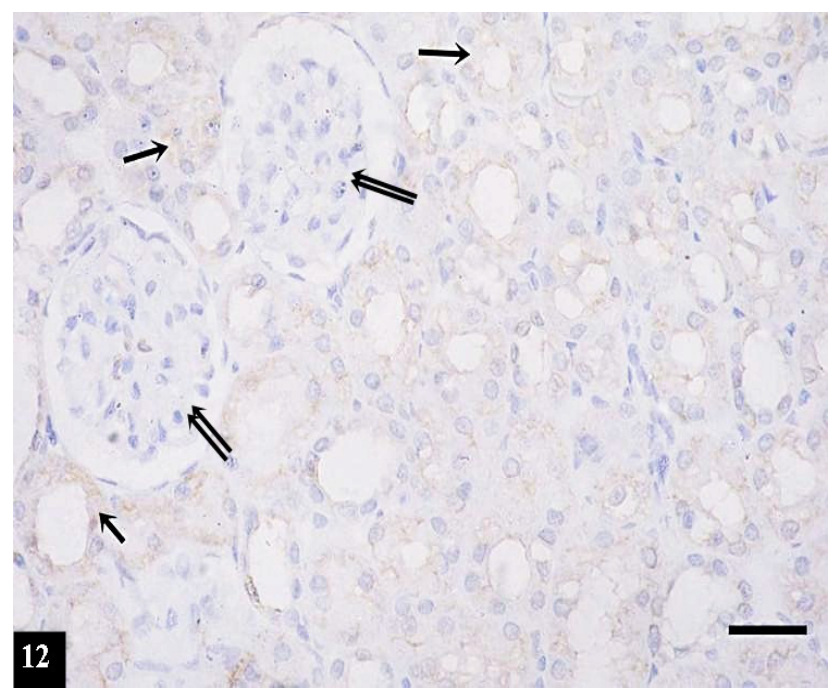

Fig. 12: A photomicrograph of immunohistochemical staining for iNOs of the control group reveals faint positive immunoreaction (arrow) in the cytoplasm of renal tubular cells. Negative immunoreaction (double arrow) in the cytoplasm of glomerular capillary endothelium is also observed.

(Immunoperoxidase technique $\times 400$, Scale bar; $20 \mu \mathrm{m}$ )

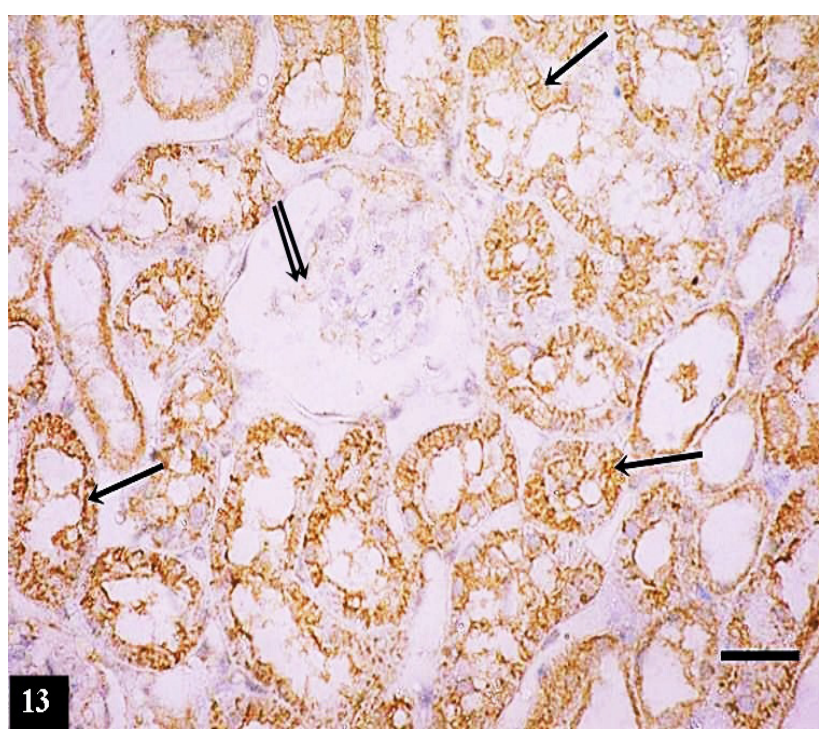

Fig. 13: A photomicrograph of immunohistochemical staining for iNOs of Taxol-treated group showing strong positive reaction (arrow) in the cytoplasm of renal tubular cells and some capillary endothelial cells (double arrow).

(Immunoperoxidase technique $\times 400$, Scale bar; $20 \mu \mathrm{m}$ )

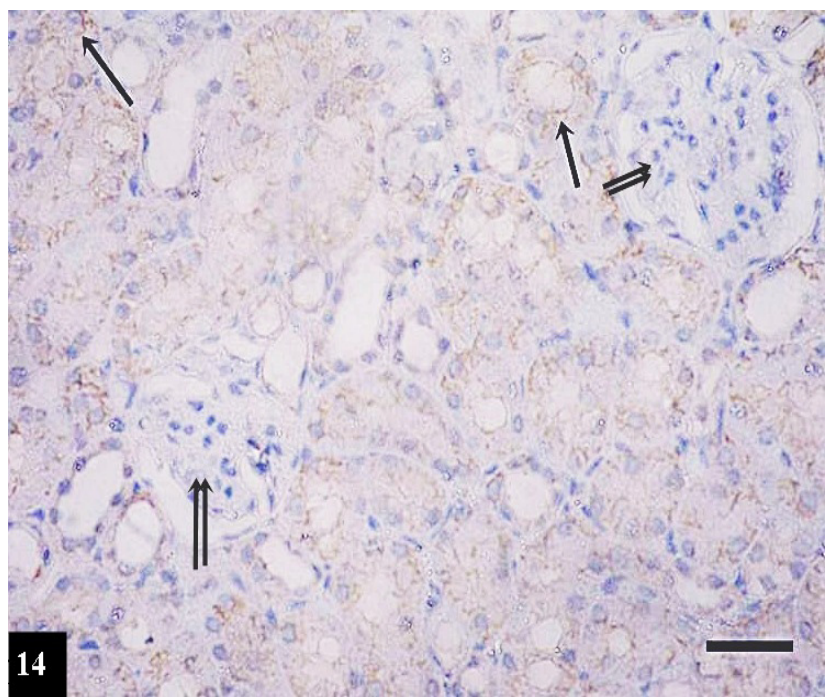

Fig. 14: A photomicrograph of immunohistochemical staining for iNOs of GNP-treated group showing weak positive immunoreaction (arrow) in the cytoplasm of renal tubular cells. Negative immunoreaction in the cytoplasm of glomerular capillary endothelium (double arrow) is also observed (Immunoperoxidase technique $\times 400$, Scale bar; $20 \mu \mathrm{m})$ 


\section{DISCUSSION}

Taxol, was shown to have anticancer effect in the early 1960 s, where it interferes with cell division by binding to tubulin, which is a key factor in mitosis, cell division and growth. This could affect regenerative activity of many organs including renal parenchyma ${ }^{[8,15]}$.

In the current study, examination of $H \& E$ stained sections of the treated group, renal cortex showed focal areas of renal affection, and renal corpuscles containing glomeruli with congested capillaries. Cellular infiltration and extravasation were seen between renal tubules. Some renal tubules were lined by tubular cells with detached basal lamina while others had dark apoptotic nuclei. Alike, $\operatorname{Rabah}^{[8]}$ observed that administration of taxol resulted in marked nephrotoxicity even when given in medical therapeutic doses $(0.6 \mathrm{mg} / \mathrm{kg})$.

Taxol exert their cytotoxic effects through production of reactive oxygen species (ROS) and causing oxidative stress $^{[16,3]}$. Oxidative stress is defined as a disruption of the prooxidant antioxidant balance in favor of the former, leading to potential damage which may alter all function through changes in intracellular calcium or intracellular $\mathrm{pH}$, and eventually can lead to cell death ${ }^{[17]}$. In addition, Taxol induces apoptosis through autolytic activation of caspases-10 and -3 thought to be the triggering of apoptotic process in cancer cells treated with Taxol ${ }^{[18]}$.

Other sections in taxol-treated group showed marked vacuolations in the cytoplasm of glomerular capillary endothelium. Parietal layer of Bowman's capsule was irregular. Tubular cells were also detected with dark stained nuclei and marked cytoplasmic vacuolations. Cellular infiltration and extravasation were seen between renal tubules. The inflammatory cellular infiltration was related to oxidative stress that resulted in generation of mediators such as IL-8 and cytokine-induced neutrophil chemoattractant which attract the inflammatory cells interstitium due to destruction of the endothelial cells by the free radicals as explained by ${ }^{[19]}$.

Tokunaga, et al. ${ }^{[20]}$ attributed cytoplasmic vacuolation to the free radicals that facilitate the release of lysosomal enzymes into the cytosol with subsequent oxidation of the protein architecture of the cells causing their fragmentation. Moreover, Chen et al. ${ }^{[18]}$ reported that Texol induces caspase-independent cytoplasmic vacuolization and cell death through endoplasmic reticulum swelling.

In the present study, we used GNPs as they show little cytotoxicity, because many cytotoxicity studies reported negative results ${ }^{[21]}$. Connor et al. ${ }^{[22]}$ studied the cytotoxicity of GNPs in human cells and showed that GNPs are nontoxic up to $250 \mathrm{mM}$. Zhang et al. ${ }^{[23]}$ have noticed that GNPs by intraperitoneal injection are less toxic than oral administration at the dose of $1100 \mu \mathrm{g} / \mathrm{kg}$.
The kidney is a unique target organ for NP because of its ability to filter particles that are smaller than $10 \mathrm{~nm}$ in diameter rapidly ${ }^{[24]}$. This ability can be attributed to the presence of glomerular filtration unit, basement membrane, and inter-digitating podocytes. The application of small quantities of gold NP at low concentrations in the medical field does not create serious hazards ${ }^{[25]}$.

In the current work, GNP-treated group showed marked improvement in the structure of renal cortical tissue. Our results were in accordance with Dkhil et al. ${ }^{[26]}$ who revealed the novel therapeutic potential of GNP against renal disorders induced by $\mathrm{S}$. mansoni infection. Gold NP reduced the levels of oxidative stress and histological disruption in the kidney. In addition, they restored the expression of the affected renal genes. The curative effect of gold NP is associated with their role as free radical scavengers.

Dkhil et al. ${ }^{[27]}$ concluded that administration of GNP $(250,500$, and $1000 \mu \mathrm{g} / \mathrm{kg})$ increases the GSH levels and decreases the nitrite/nitrate and MDA levels in the brain tissue. Moreover, GNPs are not cytotoxic because they suppress reactive oxygen species (ROS) generation. Besides, they do not promote the release of proinflammatory cytokines (TNF- $\alpha$ and IL1- $\beta$ ) in the renal and hepatic tissues of rats $^{[28]}$. These properties make them suitable candidates for nano-medicine applications.

In the current research, Mallory trichrome stained sections of the control group showed minimal collagen fibers in the interstitium between renal tubules that increase in treated group and returned as the control group in GNPtreated group. Statistically, these results were revealeda highly statistically significant increase in the mean area\% of collagen fibers detected in group II as compared to the control and GNP-treated groups. Selman, et al. ${ }^{[29]}$ reported that injury of the epithelium and basement membranes by ROS represent an initial step in the occurrence of fibrosis. After which inflammatory and immune cells migrate to and proliferate in areas of injury and release numerous cytokines that lead to further inflammation and matrix remodeling. This causes an overproduction of collagen and other matrix components that are characteristic of fibrosis.

PAS stained sections of the controls' renal cortex revealed strong positive reaction at the basal lamina of the tubular cells and the brush border of PCTs which markedly decreased in taxol-treated group and returned as the control group in GNP-treated group. Statistically significant decrease in the mean optical density of PAS reaction was detected in group II as compared to the control and GNPtreated groups consistent with Rabah ${ }^{[8]}$.

Bonventre and Yang ${ }^{[30]}$ clarified that in acute kidney injury there is rapid loss of brush border and cytoskeletal integrity which leads to loss of cell junctions and loss of polarity with mislocalization of adhesion molecules and 
other membrane proteins such as the $\mathrm{Na}+/ \mathrm{K}+$-ATPase and $\beta$-integrins leading to desquamation of epithelial tubular cells.

In the current work, immunohistochemical staining for iNos in the control group revealed faint positive immunoreaction in the cytoplasm of renal tubular cells. Strong positive immunoreaction was detected in the cytoplasm of renal tubular cells and some capillary endothelial cells in taxol-treated group, while in the GNP-treated group a weak positive immunoreaction was detected in the cytoplasm of renal tubular cells which was proved statistically. These results were consistent with previous studies as the iNOS expression was low or undetectable in normal kidneys, whereas the substantial increase in the amounts of iNOS in the glomeruli and the renal interstitium was associated with nephropathies ${ }^{[31,32]}$. Also, Ma et al. ${ }^{[33]}$ found that GNP inhibited LPS-induced NO production and iNOS expression.

Nitric oxide is one of the reactive nitrogen species produced during the metabolism of L-arginine to citrulline catalyzed by nitric oxide synthase. It is known for its direct and indirect toxic effects on cells. In addition, a more important reaction of excessive NO is combination with superoxide anions $\left(\mathrm{O}^{-2}\right)$ producing peroxynitrite (ONOO-) with stronger potential for oxidation and destruction, which is responsible for much of the cytotoxicity of NO. This anion has a fairly short half-life but is able to diffuse across cell membranes ${ }^{[34]}$. The NOs had been classified depending on the tissue of origin, the neuronal NOs, the endothelial NOs and inducible NOs. inducible NOs is expressed in response to inflammatory cytokines $^{[35]}$.

Concerning statistical analysis of blood levels of urea and serum creatinine, there was a highly significant increase of the mean values of serum urea and a significant increase of the mean values of serum creatinine in taxoltreated group when compared with that of the control and GNP-treated groups. But no significant difference obtained between the control and GNP-treated groups. This suggests that renal function was compromised following the administration of taxol in agreement with Merouani et al. ${ }^{[36]}$ who found an increased nephrotoxicity in patients treated with taxol and cisplatin as compared to cisplatin alone. Abo-Salem et al. ${ }^{[37]}$ added that oxidative stress augments urea and creatinine levels in serum and albumin excretion in urine. However, GNP therapy was suggested to reverse renal failure by reversing abnormally increased blood urea and serum creatinine to normal levels. As GNPs has an anti-oxidative effect, by inhibiting the formation of ROS and scavenging free radicals ${ }^{[38]}$.

\section{CONCLUSION}

The hazardous effects of Taxol on renal cortex of rats should be considered in the risk benefit analysis of its increasing clinical use in human. GNPs may be a promise in the treatment of renal diseases.

\section{CONFLICT OF INTEREST}

There are no conflicts of interest.

\section{REFERENCES}

1. Brede C, and Labhasetwar V. Applications of nanoparticles in the detection and treatment of kidney diseases. Adv Chronic Kidney Dis. 2013; 20(6): 454-65.

2. Abdelhalim MA, and Moussa SA. The gold nanoparticle size and exposure duration effect on the liver and kidney function of rats: In vivo. Saudi J. Biol. Sci. 2013; 20(2): 177-181.

3. Ilinskaya AN, Clogston JD, McNeil SE, and Doborovolskaia M. Induction of oxidative stress by Taxol ${ }^{\circledR}$ vehicle Cremophor-EL triggers production of interleukin- 8 by peripheral blood mononuclear cells through the mechanism not requiring de novo synthesis of mRNA. Nanomedicine, 2015;11(8): 1925-1938.

4. Denker B, Robles-Osorio ML, and Sabath E. Recent advances in diagnosis and treatment of acute kidney injury in patients with cancer.Eur. J. Intern. Med. 2011; $22: 348-354$.

5. Salahudeen AK, Doshi SM, and Pawar $\mathrm{T}$. Incidence rate, clinical correlates, and outcomes of AKI in patients admitted to a comprehensive cancer center. Clin. J. Am. Soc. Nephrol. 2013; $8: 347-354$.

6. Foley EA, and Kapoor TM. Microtubule attachment and spindle assembly checkpoint signalling at the kinetochore. Nat. Rev. Mol. Cell Biol. 2013; 14: 25-37.

7. Weaver B A. How Taxol/paclitaxel kills cancer cells. Mol. Biol. Cell, 2014 ; 25(18): 2677-2681.

8. Rabah SO. Acute Taxol nephrotoxicity: Histological and ultrastructural studies of 
mice kidney parenchyma. Saudi J. Biol. Sci. 2010; 17(2): 105-114.

9. Lameire $\mathrm{N}$.Nephrotoxicity of recent anti-cancer agents . Clin. Kidney J. 2014; 7 (1): 11-22.

10. Yang C, Tian A, and Li Z. Reversible cardiac hypertrophy induced by PEG-coated gold nanoparticles in mice. Scientific reports. 2016; 6:20203. DOI: 10.1038/srep20203.

11. Bancroft J, and Layton C.The Hematoxylin and eosin. In: Suvarna SK, Layton $\mathrm{C}$ and Bancroft JD (ed). Theory and Practice of histological techniques. 7th ed. Churchill Livingstone of El Sevier, Philadelphia: 2013; Ch. 10 and $11 ; 172-214$.

12. Drury R A, and Wallington E A. Carlton's histological techniques. 1980; 5th ed. Oxford: Oxford University Press.

13. Ramos-Vara JA, Kiupel M, Baszier T, Bliven L, Brodersen B, Chelack B, et al. Suggested guidelines for immunohistochemical techniques in veterinary diagnostic laboratories. J Vet Diagn Invest. 2008; 20: 393-413.

14. Abd El-Aziz MT, Wassef MA, Rashed LA, Mahfouz S, Omar N, and Elsebaie MM. Mesenchymal Stem cells therapy in acute renal failure: possible role of hepatocyte growth factor. J Stem Cell Res Ther. 2011; 1: 109-115.

15. Jordan MA, Toso RJ, Thrower D, and Wilson L. Mechanism of mitotic block and inhibition of cell proliferation by Taxol at low concentrations. Proc. Natl. Acad. Sci. USA. 1993; 90(20): 9552-9556.

16. Meshkini A, and Yazdanparast R. Involvement of oxidative stress in taxol-induced apoptosis in chronic myelogenous leukemia K562 cells. Exp. Toxicol. Pathol. 2012; 64(4): 357-65.

17. Flora SJS, Mittal M, Pachauri V, and Dwivedi N. A possible mechanism for combined arsenic and fluoride induced cellular and DNA damage in mice. Metallomics.2012; 4: 78-90.

18. Chen TS, Wang XP, Sun L, Wang LX, Xing D, Mok M. Taxol induces caspase-independent cytoplasmic vacuolization and cell death through endoplasmic reticulum (ER) swelling inASTC-a-1 cells. Cancer Lett. 2008; 270 (1): 164-172.

19. Aydin G, Ekrem I, Mehmet A, and Osman G. Histopathological and Biochemical Changes in
Lung Tissues of Rats Following Administration of Fluoride over Several Generations. J. Appl. Toxicol. 2003; 23: 437-446.

20. Tokunaga T, Morshed S R, Otsuki S, Takayama F, Satoh T, Hashimoto K, Yasui T, Ogawa S, Kanegae H, Yokote Y, Akahane K, Kashimata M, Satoh K, and Sakagami H. Effect of antioxidants, oxidants, metals and saliva on cytotoxicity induction by sodium fluoride. Anticancer Res. 2003; 23(5): 3719-3726.

21. Spivak MY, Bubnov RV, Yemets IM, Lazarenko LM, Tymoshok NO, Ulberg ZR. Development and testing of gold nanoparticles for drug delivery and treatment of heart failure: a theranostic potential for PPP cardiology. EPMA J. 2013; 4(1): 1.

22. 22-Connor EE, Mwamuka J, Gole A, Murphy CJ, Wyatt MD. Gold nanoparticles are taken up by human cells but do not cause acute cytotoxicity. Small. 2005;1 (3):325-327.

23. Zhang $\mathrm{XD}, \mathrm{Wu} \mathrm{HY}, \mathrm{Wu} \mathrm{D}$, et al. Toxicologic effects of gold nanoparticles in vivo by different administration routes. Int $\mathrm{J}$ Nanomed. 2010; 5: 771-781.

24. Brede C, Labhasetwar V. Applications of nanoparticles in the detection and treatment of kidney diseases. Adv Chronic Kidney Dis, 2013; 20, 454-65.

25. Doudi M, Setorki M. The effect of gold nanoparticle on renal function in rats. Nanomed $\mathrm{J}$, 2014; 1, 171-9.

26. Dkhil MA, Khalil MF, Bauomy AA, Diab MS, Al-Quraishy S. Efficacy of Gold Nanoparticles against Nephrotoxicity Induced by Schistosoma mansoni Infection in Mice[J]. Biomedical and Environmental Sciences, 2016, 29 (11): 773-781.

27. Dkhil MA, Bauomy AA, Diab MS, et al. Antioxidant and hepatoprotective role of gold nanoparticles against murine hepatic schistosomiasis. Int $\mathrm{J}$ Nanomedicine, 2015; 10, 7467-75.

28. Khan HA, Abdelhalim MA, Alhomida AS, et al. Effects of naked gold nanoparticles on proinflammatory cytokines Mrna expression in rat liver and kidney. Biomed Res Int, 2013; 2013, 590730 .

29. Selman M, King TE, and Pardo A. Idiopathic pulmonary fibrosis: prevailing and evolving 
hypotheses about its pathogenesis and implications for therapy. Ann. Intern. Med. 2001; 134: 136-151.

30. Bonventre JV, and Yang L. Cellular pathophysiology of ischemic acute kidney injury. J Clin Invest. 2011; 121: 4210-4221.

31. Bank N, Aynedjian HS, Qiu JH, Osei SY, Ahima RS, Fabry ME and Nagel RL. Renal nitric oxide synthases in transgenic sickle cell mice. Kidney Int. 1996; 50(1): 184-189.

32. 32- Heeringa $P$, van Goor $H$, Moshage $H$, Klok PA, Huitema MG, de Jager A, Schep AJ and Kallenberg CG. Expression of iNOS, eNOS and peroxynitrite-modified proteins in experimental anti-myeloperoxidase associated crescentic glomerulonephritis. Kidney Int. 1998; 53(2): 382-393.

33. Ma JS, Kim WJ, Kim JJ, Kim TJ, Ye SK, Song MD, Kang H, Kim DW, Moon WK, Lee KH. Gold nanoparticles attenuate LPS-induced NO production through the inhibition of NF-kappaB and IFN-beta/STAT1 pathways in RAW264.7 cells. 2010; 23(3): 214-9.

34. Zhan XA, Xu Z R, and Li JX. Effects of fluorosis on lipid peroxidation and antioxidant systems in young pigs. Fluoride 2005; 38:157-161.

35. Tamanini C, Basini G, Grasselli F, and Tirelli M. Nitric oxide and ovary. J. Anim. Sci. 2002; 81(2): 1-7.

36. Merouani A, Davidson SA, Schrier RW. Increased nephrotoxicity of combination Taxol and cisplatin chemotherapy in gynecologic cancers as compared to cisplatin alone. Am. J. Nephrol. 2001; 17, 53.

37. Abo-Salem OM, El-Edel RH, Harisa GE, ElHalawany N,and Ghonaim MM. Experimental diabetic nephropathy can be prevented by propolis: Effect on metabolic disturbances and renal oxidative parameters. Pak J Pharm Sci. 2009; 22: 205-210.

38. Barath ManiKanth S, Kalishwaralal K, Sriram M, et al. Anti-oxidant effect of gold nanoparticles restrains hyperglycemic conditions in diabetic mice. J Nanobiotechnol. 2010;8(1): 1. 
الملغص العربى

\title{
دور جزيئات الذهب الاقيقة فى ضرر القشرة الكلوية الناتج عن التاكسول فى ذكور الجرذان

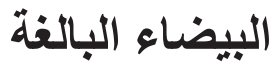

\author{
سماح محمد أحمد و مهاز زايد محمد و عبير عبد العظيم محمود

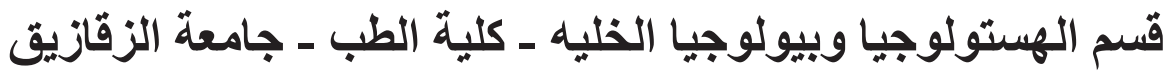

المقدمة: التاكسول هو علاج كيمياوي يستخدم في علاج العديد من الأورام السرطانية ويعتبر التسمم الكلوي من أكثر مضاعفات العلاج الكيمياوي. الهوف من البحث: تالهرف من هذا البحث هو اختبارفاعلية جزيئات الذهب الدقبقة في منع التسمم الكلوى الناتج عن التاكسول فى ذكور الجرذان البيضاء البالغة. تونة مواد وطرق البحث: استخدم في هذا البحث ثلاثثون من ذكور الجرذان البيضاء البالغة ، تم تقسيمهم الى ثلاثة مجمو عات.

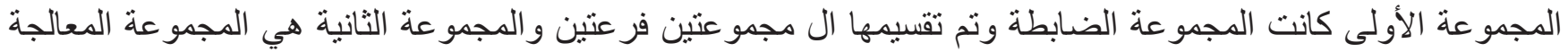

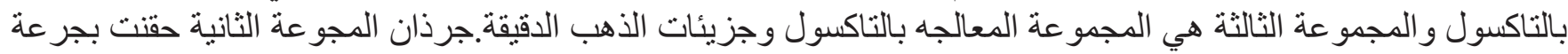

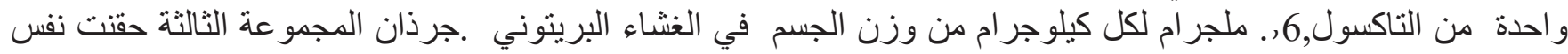

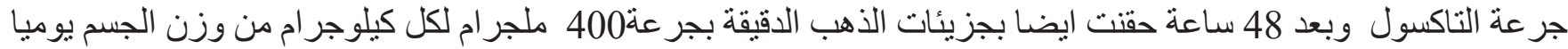

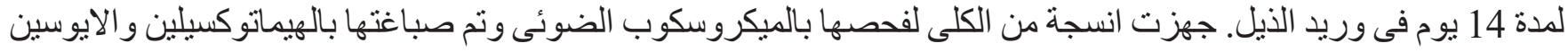

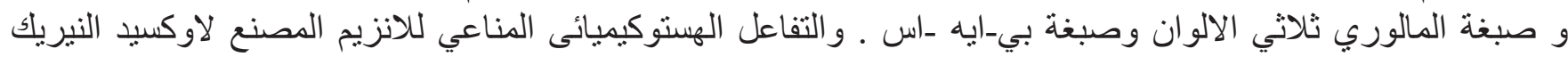

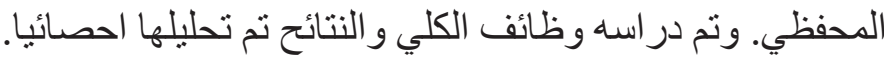

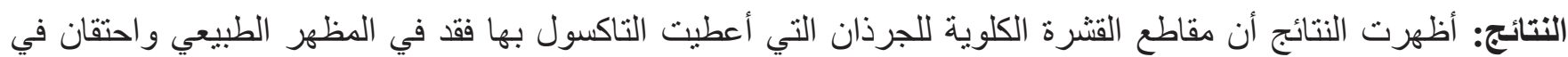

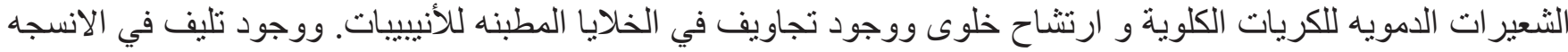

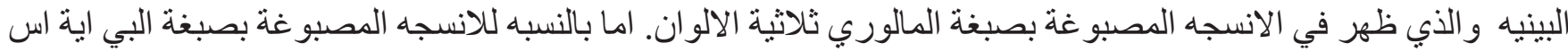

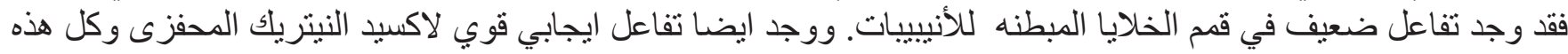

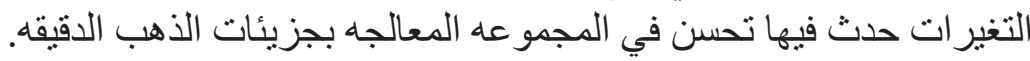
الإستنتاج: من هذه الدر اسة كان من الو اضح أن جزيئات الذهب الدقيقه تعتبر علاج مبشر للتسمم الكلوي الناتج عن التاكسول. 